\title{
EKSPERIMENTASI PENGGUNAAN MACROMEDIA FLASH DAN POWERPOINT DALAM PEMBELAJARAN BANGUN RUANG PRISMA DAN LIMAS
}

\author{
(EXPERIMENTATION OF THE USE OF MACROMEDIA FLASH AND \\ POWERPOINT IN LEARNING SOLID FIGURE OF PRISM AND PYRAMID)
}

\author{
Arif Ganda Nugroho, Purwanti \\ Prodi S1 Pendidikan Matematika Universitas Muhammadiyah Banjarmasin, SDLB Martapura \\ Email : arif.gnugroho@gmail.com
}

\begin{abstract}
ABSTRAK
Tujuan penelitian ini adalah untuk mengetahui apakah pembelajaran matematika dengan media pembelajaran Macromedia Flash menghasilkan prestasi belajar matematika yang lebih baik daripada pembelajaran dengan media Powerpoint. Penelitian ini merupakan penelitian eksperimen semu dengan populasi seluruh siswa kelas VIII SMP di Banjarmasin. Sampel penelitian ini adalah siswa kelas VIII A sebagai kelas eksperimen 1 yang dikenai media pembelajaran Macromedia Flash dan siswa kelas VIII B sebagai kelas kontrol yang dikenai media pembelajaran Powerpoint pada materi Bangun Ruang Sisi Datar Prisma dan Limas. Dari hasil penelitian dapat disimpulkan bahwa terdapat perbedaan yang signifikan prestasi belajar matematika yang diberikan pembelajaran dengan Macromedia Flash memberikan efek yang berbeda pada pembelajaran dengan media Powerpoint. Dengan melihat rataan dari prestasi belajar yang dihasilkan oleh masing-masing penggunaan media pembelajaran Macromedia Flash lebih baik dari pada media pembelajaran Powerpoint.
\end{abstract}

Kata kunci : media pembelajaran, macromedia flash, powerpoint

\begin{abstract}
The purpose of this study is to find out whether learning mathematics with Macromedia Flash teaching media produced mathematics-learning achievements better than learning with PowerPoint media. This research is a quasi-experimental study with a population of all eighth grade students of SMP in Banjarmasin. The sample of this study was class VIII A students as the experimental class 1 which was subjected to Macromedia Flash learning media and class VIII B students as the experimental class 2 which was subjected to PowerPoint learning media on the material of constructing solid figure of Prism and Pyramid. From the results of the study, it could be concluded that there were significant differences in mathematics learning achievement using Macromedia Flash compared with using PowerPoint media. After looking at the average of the learning achievements generated the use of Macromedia Flash teaching media had better results than the use of PowerPoint teaching media.
\end{abstract}

Keywords: Teaching Media, Macromedia Flash, PowerPoint 


\section{PENDAHULUAN}

Tuntutan zaman mendorong manusia untuk lenih kreatif dalam mengembangkan atau menerapkan matematika sebagai ilmu dasar dan terapan. Matematika sebagai alat dalam pengembangan teknologi dan industri yang hamper setiap segi kehidupan di zaman sekarang ini menggunakan matematika baik langsung maupun tidak langsung.

Keberhasilan seorang siswa dalam mempelajari matematika ditandai dengan prestasi belajar. Prestasi belajar siswa yang baik akan dipengaruhi oleh banyak faktor baik dari dalam diri siswa maupun dari luar diri siswa, misalnya faktor dari dalam adalah aktivitas belajar siswa, motivasi dan minat belajar siswa sedangkan faktor dari luar diri siswa adalah metode dan model pembelajaran, media pembelajaran dan alat peraga pembelajaran yang digunakan oleh guru pada saat mengajar.

Belajar matematika adalah proses dimana matematika itu ditemukan dan dibangun manusia, sehingga dalam pembelajaran matematika harus lebih dibangun oleh siswa dari pada ditanamkan oleh guru. Perlu dicarikan formula pembelajaran yang tepat, sehingga dapat meningkatkan prestasi belajar siswa. Seorang guru harus terus berusaha menyusun dan menggunakan berbagai metode pembelajaran yang bervariasi agar siswa tertarik belajar matematika dan bersemangat mengerjakan tugas matematika. Salah satunya dengan menggunakan media pembelajaran interaktif.

Menurut Sudjana dan Rivai dalam Azhar Arsyad (2010), mengemukakan manfaat media pembelajaran dalam proses belajar siswa, yaitu:

1. Pembelajaran akan lebih menarik perhatian siswa sehingga dapat menumbuhkan motivasi belajar.

2. Bahan pembelajaran akan lebih jelas maknanya sehingga dapat lebih dipahami oleh siswa dan memungkinkannya menguasai dan mencapai tujuan pembelajarannya.

3. Metode mengajar akan lebih bervariasi, tidak semata-mata komunikasi verbal melalui penuturan kata-kata oleh guru, sehingga siswa tidak bosan dan guru tidak kehabisan tenaga, apalagi kalau guru mengajar pada setiap jam pelajaran.

4. Siswa dapat lebih banyak melakukan kegiatan belajar sebab tidak hanya mendengarkan uraian guru, tetapi juga aktivitas lain seperti mengamati, melakukan, mendemonstrasikan, memerankan, dan lainlain.

Dikutip dari buku Warsita (2008) program multimedia interaktif mempunyai kelebihan antara lain sebagai berikut :

1. Fleksibel, baik dalam pemberian kesempatan untuk memilih isi mata pelajaran yang disajikan, juga variasi serta penempatan untuk diakses.

2. Self-Pacing yaitu bersifat melayani kecepatan belajar individu, artinya kecepatan waktu pemanfaatan sangat tergantung pada kemampuan dan kesiapan masing-masing peserta didik yang menggunakannya.

3. Content-Rich yaitu bersifat kaya isi, artinya program ini menyediakan informasi yang cukup banyak.

4. Interaktif, yaitu bersifat komunikasi dua arah.

5. Individual, yaitu bersifat melayani kecepatan belajar individual.

Mengingat pentingnya prestasi belajar siswa, guru diharapkan dapat menciptakan situasi belajar mengajar yang lebih menarik dan lebih melibatkan aktivitas belajar siswa sehingga dapat meningkatkan prestasi belajar siswa, salah satunya dengan memanfaatkan software presentasi Macromedia Flash dan Powerpoint di dalam pembelajaran matematika.

Bedasarkan hasil observasi awal dan wawancara dengan guru metematika diperoleh informasi bahwa siswa cenderung sulit dalam memahami konsep dasar mengenai bangun ruang seperti letak unsur-unsurnya yang cenderung berada di bagian dalam bangun ruang sehingga guru yang menggunakan alat peragapun masih terasa sulit untuk menunjukkan unsur tersebut dikarenakan keterbatasan dalam membuat alat peraga yang dimaksud. Oleh sebab itu dibutuhkan media pembelajaran lain yang lebih inovatif dan kontekstual yang lebih bisa memperlihatkan konsep dasar bangun ruang tersebut denganh lebih jelas.

Berdasarkan hasil observasi tersebut maka penggunaan media pembelajaran interaktif seperti Macromedia Flash dan Powerpoint lebih baik dalam meningkatkan prestasi belajar siswa dalam pembelajaran bangun ruang sisi datar Prisma dan Limas.

\section{METODE PENELITIAN}


Jenis penelitian ini adalah penelitian lapangan. Penelitian lapangan (Field Research) yaitu penelitian dilakukan dalam situasi ilmiah akan tetapi didahului oleh intervensi (campur tangan) dari pihak peneliti. Penelitian ini dilakukan dengan terjun langsung ke lapangan untuk meneliti Penggunaan Media Pembelajaran Macromedia Flash dan Powerpoint pada materi Limas dan Prisma. Metode yang digunakan dalam penelitian ini adalah metode eksperimen. Sedangkan pola penelitiannya menggunakan Control-Group Experiment yang menggunakan lebih dari satu kelompok yang terdiri dari kelompok eksperimen (experimental group) dan kelompok pembanding (control group). Kelas-kelas observasi diberi perlakuan yang berbeda. Tujuannya adalah untuk mengetahui ada tidaknya perbedaan pengaruh akibat perlakuan yang berbeda tersebut.

Sampel penelitian ini adalah siswa VIII SMP di Banjarmasin. Kelas VIII.A berjumlah 28 siswa yang dikenai perlakuan menggunakan media pembelajaran Macromedia Flash dan kelas VIII.B berjumlah 28 siswa dikenai perlakukan menggunakan media pembelajaran Powerpoint. Penelitian ini dilaksanakan mulai bulan April - Juni 2018 disemester genap tahun ajaran 2017/2018. Penelitian ini dilaksanakan sebanyak 6 kali pertemuan materi dan 2 kali pertemuan pelaksanaan ujian tertulis.

Teknik pengumpulan data yang digunakan dalam penelitian ini adalah soal tes prestasi belajar berbentuk soal essay, tes dilakukan pada pertemuan ketiga, keempat dan keenam dengan bentuk tes tertulis yang jumlah soal tesnya adalah 6 soal essay. Teknik pengumpulan data selanjutnya adalah dokumentasi yaitu data hasil tes tertulis siswa, materi media pembelajaran Macromedia Flash dan Powerpoint dan foto-foto kegiatan pembelajaran serta unsur penunjang lainnya. Teknik selanjutnya adalah Wawancara yaitu proses tanya jawab dalam penelitian yang berlangsung secara lisan, bertatap muka dan mendengarkan secara langsung informasiinformasi dari narasumber, wawancara digunakan untuk melengkapi dan memperkuat data yang diperoleh peneliti.

Data hasil belajar siswa dianalisis dengan menggunakan statistika analitik parametrik dan non parametrik. Statistika analitik yang digunakan adalah uji beda yaitu uji t atau uji Mann-Whiteney (uji U). sebelum mengadakan uji tersebut terlebih dahulu dilakukan perhitungan statistika meliputi rata-rata dan standar deviasi. Uji t digunakan apabila data berdistribusi normal dan homogen.
Sedangkan uji Mann-Whitney (uji U) digunakan jika salah satu data atau keduanya tidak berdistribusi normal.

\section{HASIL DAN PEMBAHASAN}

\section{Uji Beda Prestasi Belajar Siswa}

Rangkuman hasil belajar siswa dari tes akhir yang diberikan dapat dilihat pada table berikut :

Tabel 1 Deskripsi Prestasi Belajar Siswa

\begin{tabular}{lcc}
\hline & $\begin{array}{c}\text { Kelas } \\
\text { Eksperimen }\end{array}$ & Kelas Kontrol \\
\hline Nilai Tertinggi & 90,3 & 83,5 \\
Nilai Terendah & 53,4 & 50,6 \\
Rata-Rata & 84,8 & 67,5 \\
Standar Deviasi & 15,28 & 16,37 \\
\hline
\end{tabular}

\section{Uji Normalitas dan Homogenitas}

1. Uji Normalitas

Uji normalitas dilakukan untuk mengetahui kenormalan distribusi data kemampuan awal siswa yang menggunakan uji Liliefors.

Tabel 2. Rangkuman uji Normalitas

\begin{tabular}{llll}
\hline Kelas & $L_{\text {hitung }}$ & $L_{\text {tabel }}$ & Kesimpulan \\
\hline Kontrol & 0,1293 & 0,1658 & Normal \\
Eksperimen & 0,0879 & 0,1634 & Normal \\
\hline \multicolumn{1}{c}{$\alpha=0,05$} & & &
\end{tabular}

Tabel di atas menunjukkan bahwa $L_{\text {hitung }}$ untuk kelas kontrol lebih kecil dari pada $L_{\text {tabel }}$ pada taraf signifikansi $\alpha=0,05$ sehingga hasil belajar matematika dikelas kontrol berdistribusi normal. Demikian juga untuk untuk kelas eksperimen $L_{\text {hitung }}$ lebih kecil dari pada $L_{\text {tabel, }}$ artinya hasil belajar matematika dikelas eksperimen berdistribusi normal. Maka dapat dinyatakan bahwa pada taraf signifikansi $\alpha=0,05$ kedua kelas berdistribusi normal.

\section{Uji Homogenitas}

Setelah dilakukan perhitungan ternyata kedua data berdistribusi normal, sehingga dapat dilanjutkan dengan uji homogenitas varians. Uji ini bertujuan untuk mengetahui apakah prestasi belajar siswa pada kelas eksperimen dan kelas kontrol bersifat homogen atau tidak homogen.

Tabel 3. Rangkuman Uji Homogenitas

\begin{tabular}{lllll}
\hline Kelas & Varians & $\mathbf{F}_{\text {hitung }}$ & $\mathbf{F}_{\text {tabel }}$ & Kesimpulan \\
\hline Kontrol & 271,106 & \multirow{2}{*}{1,1709} & 1,88 & Homogen \\
\cline { 1 - 2 } Eksperimen & 231,536 & & & \\
\hline
\end{tabular}

$\alpha=0,05$ 
Berdasarkan tabel di atas diketahui bahwa pada taraf signifikansi $\alpha=0,05$ didapatkan $F_{\text {hitung }}$ kurang dari $F_{\text {tabel. }}$. Hal itu berarti hasil belajar kedua kelas bersifat homogen.

\section{Uji t}

Data berdistribusi normal dan homogen, maka uji beda yang digunakan adalah uji t. Berdasarkan hasil perhitungan yang terdapat pada lampiran 41 , didapat $t_{\text {hitung }}=3,748$ sedangkan $t_{\text {tabel }}=2,005$ pada taraf signifikansi $\alpha=0,05$ dengan derajat kebebasan $(\mathrm{dk})=55$. Harga $t_{\text {hitung }}$ lebih besar dari $t_{\text {tabel, }}$ dan lebih besar dari - $t_{\text {tabel }}$ maka $\mathrm{H}_{\mathrm{a}}$ diterima dan $\mathrm{H}_{0}$ ditolak. Jadi, dapat disimpulkan bahwa terdapat perbedaan yang signifikan antara hasil belajar siswa di kelas kontrol dengan kelas eksperimen.

Berdasarkan hasil pengujian yang telah diuraikan, maka terbukti bahwa terdapat perbedaan yang signifikan antara hasil belajar matematika siswa yang pembelajarannya menggunakan Macromedia Flash sebagai media pembelajaran dengan hasil belajar siswa yang pembelajarannya Powerpoint pada materi Bangun Ruang Sisi Datar Prisma dan Limas pada siswa kelas VIII SMP di Banjarmasin.

Dari kedua jenis perlakuan di atas, pembelajaran matematika yang menggunakan Macromedia Flash lebih berpengaruh terhadap hasil belajar matematika siswa bila dibandingkan dengan pembelajaran matematika yang menggunakan Powerpoint $\mathrm{Hal}$ tersebut dapat dilihat dari nilai rata-rata yang diperoleh masingmasing kelompok siswa yang dikenai perlakuan pada setiap pertemuan dan dari nilai rata-rata tes akhir dimana hasil belajar pada kelompok eksperimen menunjukkan nilai rata-rata yang lebih tinggi dibandingkan dengan kelompok kontrol.

Dari hasil tes akhir juga menunjukan nilai ratarata kedua kelas menurut peneliti masih cukup rendah. Walaupun pada kelas eksperimen nilai rata-rata kelasnya di atas nilai ketuntasan secara klasikal masih ada 6 orang yang belum tuntas dan satu orang tidak mengikuti tes akhir dan 11 orang tidak tuntas serta tiga orang yang tidak mengikuti tes akhir dikelas kontrol.

Rendahnya hasil belajar pada kedua kelas tersebut dikarenakan beberapa faktor, seperti banyaknya bentuk prisma dan limas, kurangnya penjelasan pada materi-materi sebelumnya khususnya untuk diagonal sisi pada bangun datar segi-n, dan kesulitan ketika menyesuaikan rumus dasar yang tersedia untuk menyesuaikan pada bentuk prisma dan limas yang diketahui, serta faktor-faktor lain baik faktor dari dalam diri siswa seperti motivasi belajar matematika siswa yang masih kurang, keinginan untuk bisa matematika juga kurang dilihat dari tidak belajarnya ketika akan melakukan posttes atau tes akhir, dan lainnya serta faktor luar, dan faktor lingkungan belajar.

Terbatasnya waktu yang tersedia dalam menyelesaikan soal kemungkinan juga merupakan salah satu faktor penyebab masih rendahnya hasil belajar siswa kedua kelas tersebut. Hal ini disebabkan masing-masing siswa membutuhkan waktu yang berbeda dalam menguasai materi pelajaran dan menyelesaikan soal diberikan walaupun mereka memiliki kemampuan tinggi.

Selain yang telah disebutkan, salah satu faktor yang mungkin juga penyebab rendahnya hasil belajar dikelas eksperimen adalah kesalahan peneliti sendiri yang kurang lengkap dalam membuat materi yang disajikan kepada siswa dalam bentuk Macromedia Flash. Peneliti hanya memberikan satu bentuk prisma dan limas untuk menunjukan bagian-bagian unsur-unsur pada prisma dan limas tersebut. Karena setelah dilakukan wawancara dengan beberapa siswa, siswa merasa kesulitan ketika diberikan soal dengan bentuk prisma dan limas yang berbeda dari contoh yang ditampilkan pada Macromedia Flash.

\section{KESIMPULAN}

Berdasarkan hasil analisis dan pembahasan maka dapat diambil kesimpulan dalam penelitian adalah sebagai berikut

1. Prestasi belajar siswa yang diajarkan dengan menggunakan Macromedia Flash dilihat dari rata-rata kelas pada tes akhir adalah 84,8 . Nilai tersebut berada pada kualifikasi Amat Baik.

2. Prestasi belajar siswa yang diajarkan dengan menggunakan media pembelajaran Powerpoint dilihat dari nilai rata-rata kelas adalah 67,5. Nilai tersebut berada pada kualifikasi cukup.

3. Hasil rata-rata prestasi belajar siswa menunjukkan perbedaan yang signifikan antara prestasi belajar siswa yang diberikan pembelajaran menggunakan media pembelajaran Macromedia Flash lebih baik daripada prestasi belajar siswa yang menggunakan media pembelajaran Powerpoint. Kedua media pembelajaran dapat dijadikan alternatif variasi dalam pembelajaran geometri khususnya bangun ruang sisi datar prisma dan limas. 


\section{DAFTAR PUSTAKA}

Arikunto, Suharsimi. (2006). Prosedur Penelitian: Suatu Pendekatan Praktik. Jakarta, Rineka Cipta.

Arsyad, Azhar. (2010). Media Pembelajaran. Jakarta, Raja Grafindo Pustaka.

Hartono, Jogiyanto. (1999). Pengenalan Komputer. Yogyakarta, ANDI.

Kurniawan, Yahya. ST. (2006). Macromedia Flash 8. Jakarta, Elex Media Komputindo.

Maizora, Syafdi. (2013). "Pembuatan Media Pembelajaran dengan Macromedia Flash 8", https://syafdiichiemaizora.files.wordpress.c om/2011/01/pengenalan-flash.pdf

Margono, S. (2007). Metodologi Penelitian Pendidikan. Jakarta, Rineka Cipta.

Priyatmoko, R.(2016). Pengembangan Multimedia Interaktif Menggunakan Macromedia Flash Pada Materi Bangun Ruang Sisi Datar Limas Dan Prisma Tegak Untuk Siswa Mts/SMP
Kelas VIII (Doctoral dissertation, Universitas Muhammadiyah Ponorogo).

Sudjana. (2002). Metoda Statistika. Bandung: Tarsito.

Sudjana, Nana. (2008). Dasar-Dasar Proses Belajar Mengajar. Bandung, Sinar Baru Algensindo.

Sutopo, Ariesto Hadi. (2002). Animasi dengan Macromedia Flash Berikut Action Script. Jakarta, Salemba Infotek.

Setyono, T., Afri, L. E., \& Deswita, H. (2017). Pengembangan Media Pembelajaran Matematika Dengan Menggunakan Macromedia Flash Pada Materi Bangun Ruang Kelas VIII Sekolah Menengah Pertama. Jurnal IImiah Mahasiswa FKIP Prodi Matematika, 2(1).

Warsita, Bambang. (2008). Teknologi Pembelajaran (landasan dan aplikasinya). Jakarta, Rineka Cipta. 